Izvirni znanstveni članek/Original scientific article

\title{
Ocena prehranskega stanja starejših v socialnovarstvenem zavodu
} Assessment of the nutritional status of the elderly in a residential home

\author{
Nika Urh, Katarina Babnik, Doroteja Rebec, Tamara Poklar Vatovec
}

\section{Ključne besede: starejši; jedilniki; institucionalna oskrba; prehranska ogroženost}

Key words: elderly; menus; institutional care; nutritional risk

Nika Urh, dipl. dietet., mag. diet.

doc. dr. Katarina Babnik, univ. dipl. psih.

viš. pred. Doroteja Rebec, dipl. m. s., mag. zdr. nege

doc. dr. Tamara Poklar Vatovec, univ. dipl. ing. živ. tehn.

Kontaktni e-naslov/ Correspondence e-mail: tamara.vatovec@fvz.upr.si

Vse/All: Univerza na Primorskem, Fakulteta za vede o zdravju, Polje 42, 6310 Izola, Slovenija

\section{IZVLEČEK}

Uvod: Eden od dejavnikov kakovosti življenja starejših $\mathrm{v}$ socialnovarstvenem zavodu je prehrana. Namen raziskave je bil proučiti prehransko stanje in ponuditi predloge za izboljšanje prehrane starejših $\mathrm{v}$ socialnovarstvenem zavodu.

Metode: $\mathrm{V}$ raziskavi je bila uporabljena kvantitativna opisna metoda raziskovanja. Analizirani so bili dnevni jedilniki v socialnovarstvenem zavodu in na vzorcu starejših $(n=48)$ izvedena analizo dejanskega vnosa hranil in prehranskega statusa. Prehransko stanje je bilo ugotovljeno na podlagi indeksa telesne mase in vprašalnika Mini prehranski pregled. Vključeni v raziskavo so imeli prehrano, pri kateri dietne prilagoditve niso bile potrebne.

Rezultati: Povprečna energijska vrednost ponujenih jedilnikov je znašala 8457 kJ (2021 kcal) na dan, 17 hranil je odstopalo od priporočil. Moški $(\mathrm{M})$ in ženske $(\check{Z})$ se statistično pomembno razlikujejo v deležu ostanka maščob $(\mu \mathrm{M}=16 \%, \mu \check{Z}=24 \%, p=0,036)$, holesterola $(\mu \mathrm{M}=15 \%, \mu \check{Z}=26 \%, p=0,035)$, vitamina $\mathrm{D}(\mu \mathrm{M}=15 \%, \mu \check{\mathrm{Z}}=27 \%, p=0,017)$ in vitamina $\mathrm{B}_{12}(\mu \mathrm{M}=17 \%, \mu \check{\mathrm{Z}}=25 \%, p=0,016)$. Indeks telesne mase je pokazal, da nihče od starejših, ki so bili vključeni v raziskavo, ni bil podhranjen ali v kategoriji debelost III. stopnje.

Diskusija in zaključek: Raziskava je potrdila potrebo po sistematičnem spremljanju kakovosti prehrane starejših v socialnovarstvenih zavodih. Da bi starejšim zagotovili ustrezno prehransko oskrbo, je potrebno sodelovanje medpoklicnega tima s starejšimi in njihovimi družinskimi člani.

\section{ABSTRACT}

Introduction: Nutrition is one of the factors that determine the quality of life of the elderly in a residential home. The purpose of the study was to investigate nutritional status and propose suggestions to improve nutrition among the elderly in a residential home.

Methods: A quantitative descriptive research method was used. Analysed were the weekly menus in one of the Slovenian residential homes, performed an analysis of the actual nutrient intake and assessed the nutritional status of the elderly $(n=48)$. The nutritional status was assessed by means of the body mass index and the mini nutritional assessment tool. The participants included in the study had a diet without any special dietary adjustments.

Results: The average energy value of weekly menus amounted to $8457 \mathrm{~kJ}$ (2021 kcal) per day. 17 nutrients deviated from the recommendations. Men (M) and women (W) statistically significantly differed in the proportion of residual fats $(\mu \mathrm{M}=16 \%, \mu \mathrm{W}=24 \%, p=0.036)$, cholesterol $(\mu \mathrm{M}=15 \%, \mu \mathrm{W}=26 \%, p=$ $0.035)$, vitamin $\mathrm{D}(\mu \mathrm{M}=15 \%, \mu \mathrm{W}=27 \%, p=0.017)$ and vitamin $\mathrm{B}_{12}(\mu \mathrm{M}=17 \%, \mu \mathrm{W}=25 \%, p=0.016)$. The body mass index showed that none of the elderly included in the study was malnourished or in the class III obesity.

Discussion and conclusion: The study confirmed the need for systematic monitoring of the elderly's quality of nutrition in a residential home. In order to provide the elderly with adequate nutritional care, the cooperation of an inter-professional team with the elderly and their family members is necessary.
Članek je nastal na osnovi magistrskega dela Nike Urh Vrednotenje jedilnikov, prehranski vnos in ocena prehranskega stanja starostnikov $v$... (2016).

Prejeto/Received: 7. 3. 2017

Sprejeto/Accepted: 25. 7. 2017 


\section{Uvod}

V svetu se v povezavi z leti upokojevanja populacijo starejših pogosto opredeljuje kot osebe, stare $60 \mathrm{oz}$. 65 let in več, vendar pa je glede na demografske trende staranja prebivalstva pričakovati, da se bo ta arbitrarno določena meja, kdo so starejši, $\mathrm{v}$ prihodnosti spreminjala (Hlebec, et al., 2013). Pri kronološkem določanju starostne meje pa se $\mathrm{v}$ statistikah kot starejše najpogosteje opredeljuje osebe, stare 65 let in več (Hlebec, et al., 2013; Razpotnik, 2017). Staranje ljudem prinaša številne biološke, psihološke in socialne spremembe, ki jih pogosto spremljajo tudi različna kronična obolenja (Skela Savič, et al., 2010). Vse to lahko vpliva na prehranjevalne navade in prehranjenost starejših (de van der Schueren, 2015). Prehrana pa vpliva na fizično in duševno zdravje ter na samostojnost posameznika pri izvajanju življenjskih aktivnosti (Eide, et al., 2015) in tako tudi na kakovost življenja in umrljivost starejših (Kvamme, et al., 2011; Thomas, et al., 2013). Staranje pogosto spremljajo prehransko tveganje, pomanjkljiva ali prekomerna prehranjenost (Drewnowski, et al., 2003; Leslie \& Henkley, 2015).

V starostise zmanjša bazalna presnova, kiposledično, skupaj z zmanjšano gibalno aktivnostjo, privede do zmanjšanih energijskih potreb (Elmadfa \& Meyer, 2008). Skozi celotno obdobje odraslosti se energijske potrebe zmanjšajo za približno $20 \%$ (Gabrijelčič Blenkuš, et al., 2010). Zmanjšanje energijskih potreb vpliva na količino in volumen zaužite hrane, kar $\mathrm{v}$ povezavi s starostnimi fiziološkimi spremembami lahko privede do pomanjkljivega energijskega vnosa ter pomanjkljivega vnosa makro- in mikrohranil (Power, et al., 2014). Beljakovinska energijska podhranjenost je pogostejša pri starejših v socialnovarstvenih zavodih in pri hospitaliziranih starejših kakor pri starejših, ki živijo v domačem okolju (Cederholm, 2015). Povečano tveganje za beljakovinsko energijsko podhranjenost med starejšimi v socialnovarstvenih zavodih potrjujejo številne raziskave (van Nie-Visser, et al., 2011; Donini, et al., 2013; Amorim Sena Pereira, et al., 2015), vendar pa raziskave ne dajejo zanesljivih podatkov o deležu starejših v socialnovarstvenih zavodih, pri katerih je podhranjenost prisotna ali pa je prisotno tveganje za njen pojav. Van Nie-Visser in sodelavci (2011) ugotavljajo, da se razširjenost podhranjenosti starejših v socialnovarstvenih zavodih v Evropi giblje med $2 \%$ in $85 \%$. Pregled raziskav Evropskega združenja za klinično prehrano in metabolizem (The European Society for Clinical Nutrition and Metabolism ESPEN) pa kaže na $20-40 \%$ podhranjenost starejših v socialnovarstvenih zavodih (Cederholm, 2015). Poklar Vatovec (2013) $\mathrm{z}$ raziskavo na majhnem vzorcu $(n=$ 20) starejših v socialnovarstvenem zavodu, starih 65 let in več, ugotavlja, da nihče od vključenih v raziskavo ni bil podhranjen, pri petih pa je bilo prisotno tveganje za podhranjenost. Gorjup Poženel in Skela Savič (2013) na vzorcu 117 stanovalcev socialnovarstvenega zavoda, starih med 75 in 95 let, ugotavljata tveganje za podhranjenost pri $32,5 \%$ stanovalcih in podhranjenost pri $17,9 \%$ stanovalcev.

Kljub zmanjšanju potreb po energiji v starosti, priporočila za vnos večine vitaminov in mineralov $\mathrm{v}$ starosti ostajajo podobna priporočilom za zgodnjo in srednjo odraslost (Elmadfa \& Meyer, 2008; Power, et al., 2014). Oslabljena absorpcija nekaterih vitaminov in mineralov, kot sta vitamin $B_{12}$ in kalcij, zmanjšana sposobnost sintetiziranja vitamina $\mathrm{D}$ ob sočasni manjši izpostavljenosti sončni svetlobi, pomen vnosa antioksidantov v starosti, kot so vitamin C, betakaroten in cink (Elmadfa \& Meyer, 2008), potrjujejo vlogo zagotavljanja potrebnih mikrohranil $\mathrm{v}$ starosti (Power, et al., 2014; Leslie \& Hankey, 2015) in s tem ustrezne sestave obrokov za starejše. Tudi priporočila za makrohranila so za stare 65 let in več podobna tistim za ostalo populacijo odraslih (Gabrijelčič Blenkuš, et al., 2010): (I) vnos skupnih ogljikovih hidratov $\mathrm{v}$ višini $50-70 \%$ celodnevnega energijskega vnosa; (II) vnos skupnih maščob $\mathrm{v}$ višini 15 (oz. od 20)-30\% celodnevnega vnosa; (III) vnos beljakovin v višini 10-15 (oz. do $20 \%$ ) celodnevnega vnosa. Za starejše, pri katerih je zaradi akutne ali kronične bolezni prisotno tveganje za podhranjenost ali pa so podhranjeni, morajo jedilniki zagotavljati vnos beljakovin $\mathrm{v}$ višini $1,2-1,5 \mathrm{~g}$ na kilogram telesne mase in več (Deutz, et al., 2014). Priporočeni vnos tekočine pa je najmanj 1,5 l na dan (Gabrijelčič Blenkuš, et al., 2010), v kolikor ni zdravstvenih kontraindikacij, ki bi vplivale na količino dnevno vnesene tekočine.

Podhranjenost je le eden od vidikov posledic neustreznega prehranskega vnosa pri starejših. Telesna nedejavnost ter neredna prehrana $\mathrm{z}$ veliko ogljikovimi hidrati in maščobami lahko pripeljeta do prekomerne prehranjenosti ali debelosti pri starejših (López-Contreras, et al., 2014). Pri tem je pomembno tudi dejstvo, da se podhranjenost $\mathrm{z}$ določenimi mikrohranili tudi pri starejših lahko povezuje $s$ prisotnostjo prekomerne telesne mase ali debelosti, kar potrjuje nevarnost vnosa sicer energijsko bogate, vendar z mikrohranili skope hrane (Leslie \& Hankey, 2015). V Združenih državah Amerike je med prebivalstvom, starim 65 let in več, več kot tretjina debelih (Fakhouri, et al., 2012); razširjenost debelosti pa je višja $\mathrm{v}$ starostni skupini med 65 in 74 let kot $\mathrm{v}$ skupini 75 let in več (Fakhouri, et al., 2012). V Španiji razširjenost prekomerne telesne mase in debelosti med moškimi, starimi 60 let in več, znaša $49 \%$ (prekomerna telesna masa) oz. 31,5 \% (debelost), med ženskami te starosti pa 39,8 \% (prekomerna telesna masa) oz. 40,8 \% (debelost) (Gutiérrez-Fisac, et al., 2004). López-Contreras in sodelavci (2014) prekomerno telesno maso ali debelost ugotavljajo za $32,2 \%$ starejših $\mathrm{v}$ proučevanih socialnovarstvenih zavodih. De Souto Barreto in sodelavci (2012) pa navajajo, da je $\mathrm{v}$ proučevanih socialnovarstvenih zavodih debelih približno $18 \%$ in prekomerno hranjenih 28,5\% starejših. Med le-temi je 25,8 \% žensk in 36,1 \% moških $\mathrm{s}$ prekomerno telesno maso. 
Organizirana prehrana sodi med osnovno dejavnost socialnovarstvenih zavodov in je $\mathrm{v}$ Sloveniji regulirana $\mathrm{z}$ zakonom (Zakon o socialnem varstvu, 2007) in podzakonskimi akti, kakovost prehrane pa usmerja Resolucija o nacionalnem programu o prehrani in telesni dejavnosti za zdravje 2015-2025 (2015). Pri vsakodnevnem sestavljanju jedilnikov za starejše moramo upoštevati tudi Referenčne vrednosti za energijski vnos ter vnos hranil (Nacionalni inštitut za javno zdravje, 2016). Prehransko stanje je stanje telesa, ocenjeno po tistih vidikih delovanja, ki so pod vplivom prehrane, in je rezultat prehranskega vnosa, prehranskih potreb in drugih vplivnih dejavnikov, kot so medicinski, funkcionalni, kognitivni in socialni (de van der Schueren, 2015). Kot ugotavljajo Gabrijelčič Blenkuš in sodelavci (2010), je v Sloveniji premalo raziskovanja na področju prehrane pri starejših in posledično premalo sistemskih ukrepov za izboljšanje stanja. Tako smo se odločili, da izvedemo raziskavo, ki bo pripomogla $\mathrm{k}$ razumevanju prehrane starejših in $\mathrm{k}$ oblikovanju možnih ukrepov za izboljšanje le-te $\mathrm{v}$ socialnovarstvenih zavodih.

\section{Namen in cilji}

Namen raziskave je bil proučiti prehransko stanje in ponuditi predloge za izboljšanje prehrane med starejšimi, vključenimi $\mathrm{v}$ socialnovarstveni zavod. Cilj raziskave je bil ugotoviti skladnost energijskih in hranilnih vrednosti jedilnikov $\mathrm{v}$ enem od socialnovarstvenih zavodov $\mathrm{s}$ priporočili. Zanimalo nas je tudi, kolikšen delež jedi starejši dejansko zaužijejo ter kakšna je ocena njihovega prehranskega stanja.

$S$ pomočjo raziskave smo skušali odgovoriti na naslednja raziskovalna vprašanja:

- Koliko so jedilniki v socialnovarstvenem zavodu po energijskih in hranilnih vrednostih skladni $s$ priporočili?

- Kolikšen je dejanski vnos oz. ostanek posameznih hranil pri starejših?

- Kako se moški in ženske razlikujejo v ostanku posameznih hranil?

- Kakšna je ocena prehranskega stanja starejših, ki prebivajo $\mathrm{v}$ enem od domov starejših občanov $\mathrm{v}$ Sloveniji?

\section{Metode}

$\mathrm{V}$ raziskavi smo uporabili kvantitativno opisno metodo raziskovanja. $\mathrm{V}$ prvem delu raziskave smo se usmerili $\mathrm{v}$ analizo dnevnih jedilnikov $\mathrm{v}$ socialnovarstvenem zavodu in $\mathrm{v}$ analizo dejanskega vnosa hranil za izbrani vzorec starejših ter $\mathrm{v}$ drugem delu raziskave $\mathrm{v}$ analizo prehranskega statusa vzorca starejših. $\mathrm{V}$ analizo smo vključili tedenski jedilnik za starejše, ki so uživali prehrano brez diet (sladkorna, želodčna, žolčna, vegetarijanska) in brez spremenjene konsistence hrane (sondna, kašasta, pasirana). Dejanski vnos hrane in prehransko stanje smo ugotavljali pri vsakem v vzorec vključenem posamezniku posebej.

\section{Opis instrumenta}

Podatke smo zbirali s pomočjo meritev, strukturiranega opazovanja in anketiranja. $\mathrm{V}$ prvem delu raziskave smo sedem dni tehtali pripravljene štiri obroke (zajtrk, kosilo, popoldansko malico in večerjo) za starejše s prehrano brez dietnih prilagoditev. Tehtanje jedi za posamezen obrok smo izvajali $\mathrm{v}$ kuhinji socialnovarstvenega zavoda, in sicer $\mathrm{z}$ večkratnim ponavljanjem, tako da smo pridobili točne vrednosti utežne mase celotnega obroka in posamičnih jedi, ki so posamezen obrok sestavljali. S pomočjo normativov (domskih receptur) smo iz tehtane mase jedi preračunali hranilno in energijsko vrednost obroka in celodnevnega jedilnika. Kot pripomoček pri oceni ostankov hrane smo uporabili validirani vprašalnik za ocenjevanje prehranskega vnosa (Bjornsdottir, et al., 2013; Cederholm et al., 2017; ESPEN, n. d.), in sicer slovensko verzijo $\mathrm{z}$ naslovom Vprašalnik - Ocena dnevnega vnosa hrane, ki so jo objavili Poklar Vatovec in sodelavci (2013, p. 55). Vprašalnik od ocenjevalcev zahteva, da po vsakem obroku na lestvici ocenijo, kolikšen delež jedi je oseba zaužila (lestvica: vse, polovico, četrtino, nič), ter da na podlagi pojasnil osebe zabeležijo, zakaj oseba določenega dela obroka ali celotnega obroka ni zaužila (npr. razlogi: »ni lačen/-a«; »mu/ji je slabo«;»mu/ji ni všeč vonj«; »hrana nima dobrega okusa «) (Poklar Vatovec, et al., 2013). Vprašalnik temelji na razumevanju dejanskega vnosa hrane kot razlike med ponujeno hrano in ostankom hrane.

$\mathrm{Za}$ oceno prehranskega statusa smo uporabili standardizirani vprašalnik Mini prehranski pregled (MPP; The Mini-Nutritional Assessment - MNA ${ }^{\circledR}$ ) (Guigoz, 2006) in indeks telesne mase (ITM). Vprašalnik MPP (Guigoz, 2006; Ministrstvo za zdravje RS, 2008) je sestavljen iz dveh delov. Če anketiranec v prvem delu (MPP - presejanje) doseže 12 točk, nadaljnje anketiranje ni potrebno. Če je vsota seštevka 11 točk ali manj, je treba nadaljevati z drugim delom vprašalnika (MPP - pregled). Največje možno število, ki ga posameznik s pomočjo vprašalnika lahko doseže, je 30 točk. Rezultat 24 točk ali več kaže na ustrezen prehranski status, seštevek od 17 do 23,5 točke kaže na tveganje za podhranjenost, manj kot 17 točk pa na podhranjenost (Guigoz, 2006). ITM predstavlja razmerje med dejansko telesno maso v kilogramih in telesno višino v metrih na kvadrat. Izračunamo ga po naslednji formuli (van Bokhorst-de van der Schueren, et al., 2011):

$$
\mathrm{ITM}=(\text { telesna masa }(\mathrm{kg})) /\left(\text { telesna višina }(\mathrm{m})^{2}\right)
$$


Stanje prehranjenosti glede na ITM delimo na naslednje kategorije: do 18,4 podhranjenost, od 18,5 do 24,9 normalna hranjenost, od 25,0 do 29,9 čezmerna hranjenost, od 30,0 do 34,9 debelost I. stopnje, od 35,0 do 39,9 debelost II. stopnje, 40,0 in več izredna debelost (debelost III. stopnje) (Hlastan Ribič, et al., 2012). Starejše smo stehtali $\mathrm{z}$ navadno tehtnico, za merjenje višine smo uporabili žepni meter $\mathrm{z}$ zaponko.

Pri analizi prehranskega stanja smo poleg meritev ITM uporabili tudi presejalni vprašalnik MPP, ki meri več dimenzij dejavnikov tveganja prehranske ogroženosti (ocena duševnega in telesnega stanja, samostojnost) (Poklar Vatovec, et al., 2013). MPP je napovedni instrument $\mathrm{v}$ analizi prehranskega stanja, saj identificira dejavnike tveganja za prehransko ogroženost (Poklar Vatovec, et al., 2013) in omogoča ciljane preventivne ukrepe. Drugi del MPP (pregled) vključuje tudi vprašanja $\mathrm{v}$ zvezi $\mathrm{z}$ vnosom posameznih makrohranil in živil ter dodatne meritve za osebe, pri katerih se izvaja prehranska ocena (obseg sredine nadlahti, obseg sredine meč). Za merjenje obsega nadlahti in meč smo uporabili šiviljski meter.

\section{Opis vzorca}

V raziskavi je sodelovalo 48 starejših, od tega 34 žensk in 14 moških, s povprečno starostjo 82,2 let $(s=10)$. Vsi udeleženci so imeli prehrano brez dietnih prilagoditev. Udeleženci so bili pri izvajanju vsakodnevnih življenjskih aktivnosti samostojni. Dnevne obroke so samostojno uživali večinoma $\mathrm{v}$ centralni jedilnici socialnovarstvenega zavoda ali $\mathrm{v}$ oddelčnih jedilnicah. $\mathrm{V}$ drugem delu raziskave smo zaradi nepopolnih podatkov 8 stanovalcev izključili iz raziskave.

\section{Opis poteka raziskave in obdelave podatkov}

Pred izvedbo raziskave smo pridobili ustno soglasje vodstva socialnovarstvenega zavoda in ustno soglasje udeležencev raziskave. Udeleženci so sodelovali prostovoljno, kadarkoli $\mathrm{v}$ času izvedbe raziskave so imeli tudi možnost odstopiti od sodelovanja. V kuhinji socialnovarstvenega zavoda smo sedem dni zapored vsak dan tehtali štiri obroke, in sicer zajtrk, kosilo, popoldansko malico in večerjo za starejše s prehrano brez dietnih prilagoditev. $S$ tehtanjem smo zagotavljali primerljivost porcij za vse starejše, vključene $\mathrm{v}$ raziskavo, prav tako pa smo v tednu izvajanja meritev nadzorovali razdeljevanje porcij $\mathrm{v}$ centralni jedilnici socialnovarstvenega zavoda in $\mathrm{v}$ oddelčnih jedilnicah. V kuhinji smo posamezno pripravljeno jed stehtali z digitalno kuhinjsko tehtnico Soehnle ${ }^{\circledR}$ Exacta Pure z odstopanjem do 1 g. Osebje kuhinje nam je posredovalo tudi normative $\mathrm{z}$ recepturami za pripravo jedi. Na podlagi tehtanja in normativov smo količinsko ocenili obroke in podatke vnesli v Odprto platformo za klinično prehrano (OPKP). OPKP je spletna aplikacija za prehransko obravnavo in načrtovanje prehrane bolnikov in zdravih prebivalcev (Inštitut Jožef Stefan, n. d.). Dobljene energijske in hranilne vrednosti smo primerjali $s$ smernicami za prehrano starejših (Nacionalni inštitut za javno zdravje, 2016) in ugotavljali odstopanja. Po tehtanju vsakega posameznega obroka smo s pomočjo vprašalnika za ocenjevanje prehranskega vnosa $\mathrm{v}$ jedilnici po končanem hranjenju zabeležili, kolikšen delež jedi je starostnik dejansko zaužil. Vprašalnike smo izpolnjevaliob prisotnostistarejših, ki sopovedali, koliko jedi so dejansko zaužili, količino ostankov hrane pa smo ocenili tudi sami. Če so izjemoma starejši kakšnega od obrokov na lastno željo zaradi manjših oddelčnih jedilnic zaužili v sobi, so nam pri izpolnjevanju vprašalnikov pomagali zaposleni $\mathrm{v}$ zdravstveni negi, ki smo jih o uporabi vprašalnika za ocenjevanje prehranskega vnosa poučili že pred izvedbo raziskave. Energijsko vrednost ter vrednost makro- in mikrohranil ostanka smo izračunali na podlagi ugotovljenega ostanka hrane, to je vrste in količine hrane, ki je ostala na krožniku oz. je starejši niso zaužili. S pomočjo vodenega intervjuja smo za posameznega starostnika izpolnili tudi vprašalnik MPP. Vsakega posameznika smo med raziskavo enkrat izmerili (zjutraj), in sicer telesno maso in telesno višino. Starejšim, pri katerih je presejanje s pomočjo MPP pokazalo prehransko tveganje, smo v drugem delu vprašalnika izmerili tudi obsega nadlahti in meč.

$\mathrm{Za}$ pridobitev odgovora na prvo raziskovalno vprašanje smo uporabili računalniški program Microsoft Excel, odgovore na drugo, tretje in četrto raziskovalno vprašanje pa smo ugotavljali s pomočjo statističnih analiz in programa SPSS verzija 20.0 (SPSS Inc., Chicago, IL, USA). Pri predstavitvi rezultatov smo uporabili deskriptivno statistiko (mediano in kvartile, minimalno in maksimalno vrednost ter aritmetično sredino). Za preverjanje razlik med moškimi in ženskami $\mathrm{v}$ ostanku posameznih hranil smo zaradi odstopanja od normalne porazdelitve uporabili neparametrični Mann-Whitneyev U-test.

\section{Rezultati}

Rezultati so strukturirani v skladu z zastavljenimi raziskovalnimi vprašanji. $V$ raziskavi nismo ugotavljali povezanosti vrednosti vnesenih hranil $\mathrm{z}$ obroki in prehranskim statusom starejših, saj je za tako raziskavo potrebno longitudinalno spremljanje in večje število udeležencev, zato za prvi del raziskave prikazujemo rezultate, pridobljene na vzorcu 48 starejših (analiza jedilnikov in ostanka hranil), $v$ drugem delu raziskave pa prikazujemo rezultate analize prehranskega stanja za vzorec 40 udeležencev (10 moških in 30 žensk).

\section{Energijske in hranilne vrednosti ponujenih jedilnikov}

V sklopu prvega raziskovalnega vprašanja smo preverjali, ali so jedilniki $\mathrm{v}$ socialnovarstvenem zavodu po energijskih in hranilnih vrednostih skladni $s$ priporočili, ki jih je objavil Nacionalni inštitut za 


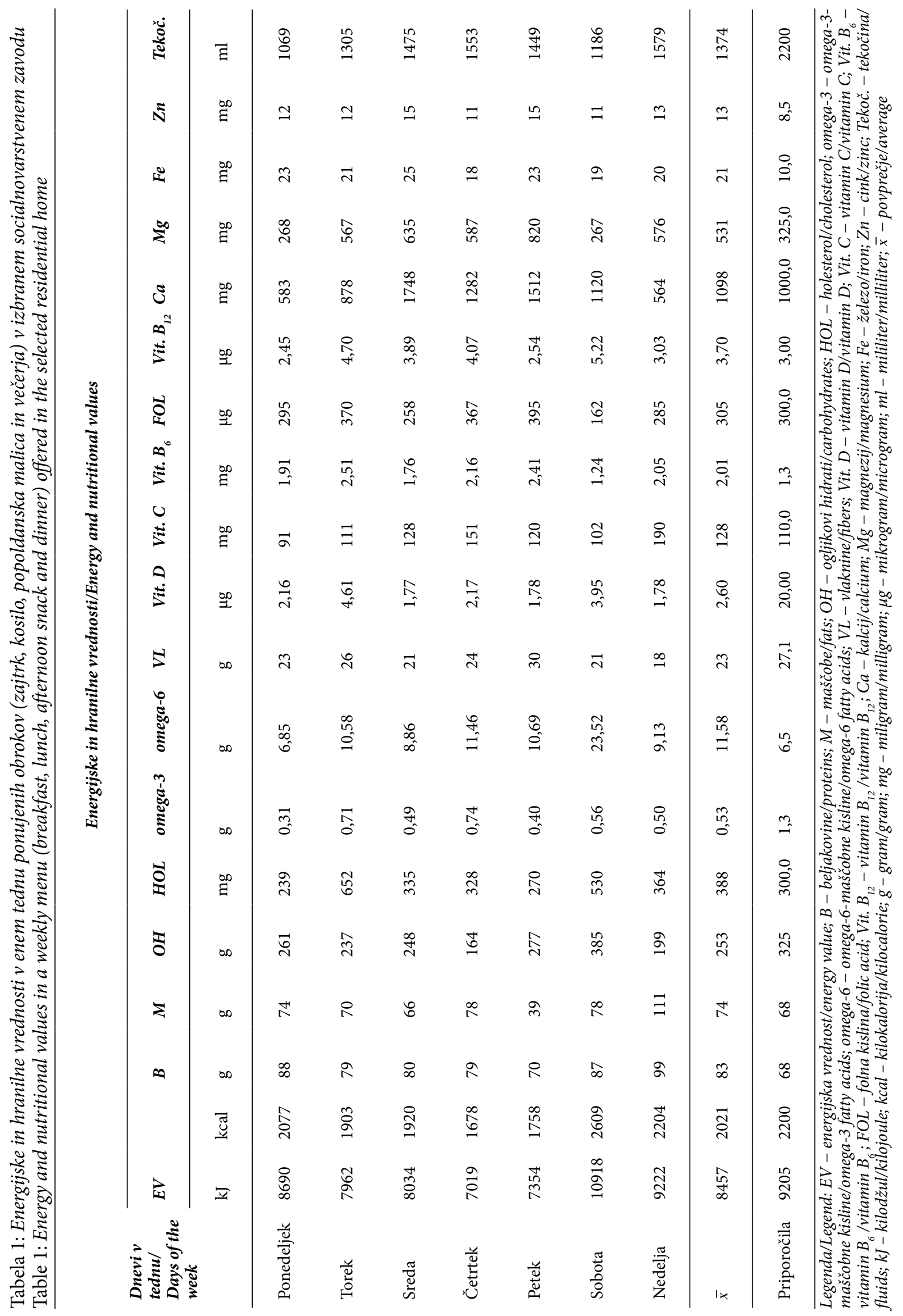


javno zdravje (2016). Tabela 1 prikazuje energijske in hranilne vrednosti ponujenih obrokov tedenskega jedilnika (od ponedeljka do nedelje) za štiri obroke, kar pomeni, da smo skupaj analizirali 28 obrokov, zajetih v sedmih dnevih izvajanja meritev. V Tabeli 2 so prikazani deleži energije beljakovin, maščob in ogljikovih hidratov jedilnikov za vsak posamezen dan $\mathrm{v}$ tednu izvedbe raziskave.

Tabela 2: Dnevni deleži energije v obliki beljakovin, maščob in ogljikovih hidratov $v$ obrokih, ponujenih $v$ enem tednu (zajtrk, kosilo, popoldanska malica in večerja)

Table 2: Daily amounts of energy in the form of proteins, fats and carbohydrates in the meals offered during one week (breakfast, lunch, afternoon snack and dinner)

\begin{tabular}{|c|c|c|c|}
\hline \multirow{2}{*}{$\begin{array}{l}\text { Dneviv } \\
\text { tednu/ } \\
\text { Days of } \\
\text { the week }\end{array}$} & \multicolumn{3}{|c|}{ Energijska vrednost/Energy value (\%) } \\
\hline & $\begin{array}{l}\text { Beljakovine/ } \\
\text { Proteins }\end{array}$ & $\begin{array}{l}\text { Maščobe/ } \\
\text { Fats }\end{array}$ & $\begin{array}{l}\text { Ogljikovi } \\
\text { hidrati/ } \\
\text { Carbohydrates }\end{array}$ \\
\hline Ponedeljek & 17 & 32 & 50 \\
\hline Torek & 17 & 33 & 50 \\
\hline Sreda & 17 & 31 & 52 \\
\hline Četrtek & 19 & 42 & 39 \\
\hline Petek & 16 & 20 & 63 \\
\hline Sobota & 13 & 27 & 59 \\
\hline Nedelja & 18 & 45 & 36 \\
\hline $\bar{x}(\%)$ & 16,7 & 32,9 & 49,9 \\
\hline
\end{tabular}

Legenda/Legend: $\bar{x}-$ povprečje/average, $\%$ - odstotek/percentage

Povprečna energijska vrednost ponujenih jedilnikov je znašala 8457 kJ (2021 kcal) (Tabela 1). Jedilniki so bili v povprečju sestavljeni iz $17 \%$ beljakovin, $33 \%$ maščob in $50 \%$ ogljikovih hidratov (Tabela 2). Kot je razvidno iz Tabele 1, so v ponujenih jedilnikih po višjih povprečnih vrednostih od dnevno priporočenih izstopala naslednja hranila: beljakovine (dosežena povprečna vrednost $(\mathrm{DPV})=83 \mathrm{~g}$, priporočena vrednost $(\mathrm{PV})=68 \mathrm{~g})$, maščobe $(\mathrm{DPV}=74 \mathrm{~g}, \mathrm{PV}=68 \mathrm{~g})$, holesterol $(\mathrm{DPV}=388 \mathrm{mg}, \mathrm{PV}=300 \mathrm{mg})$, omega $-6-$ maščobne kisline (DPV $=11,6 \mathrm{~g}, \mathrm{PV}=6,5 \mathrm{~g})$, vitamin $\mathrm{C}(\mathrm{DPV}=128 \mathrm{mg}, \mathrm{PV}=110 \mathrm{mg})$, vitamin $\mathrm{B}_{6}(\mathrm{DPV}$
$=2,0 \mathrm{mg}, \mathrm{PV}=1,3 \mathrm{mg}$ ), folna kislina (DPV $=305 \mu \mathrm{g}$, $\mathrm{PV}=300 \mu \mathrm{g})$, vitamin $\mathrm{B}_{12}(\mathrm{DPV}=3,7 \mu \mathrm{g}, \mathrm{PV}=3,0$ $\mu \mathrm{g})$, kalcij (DPV = $1098 \mathrm{mg}, \mathrm{PV}=1000 \mathrm{mg}$ ), magnezij $(\mathrm{DPV}=531 \mathrm{mg}, \mathrm{PV}=325 \mathrm{mg})$, železo $(\mathrm{DPV}=21$ $\mathrm{mg}, \mathrm{PV}=10 \mathrm{mg})$ in cink $(\mathrm{DPV}=13 \mathrm{mg}, \mathrm{PV}=8,5$ $\mathrm{mg}$ ). Povprečne tedenske vrednosti, ki niso dosegale prehranskih priporočil, je bilo zaslediti pri ogljikovih hidratih $(\mathrm{DPV}=253 \mathrm{~g}, \mathrm{PV}=325 \mathrm{~g})$, vitaminu $\mathrm{D}$ (DPV $=2,6 \mu \mathrm{g}, \mathrm{PV}=20 \mu \mathrm{g})$, omega-3-maščobnih kislinah $(\mathrm{DPV}=0,53 \mathrm{~g}, \mathrm{PV}=1,3 \mathrm{~g})$, prehranskih vlakninah $(\mathrm{DPV}=23 \mathrm{~g}, \mathrm{PV}=27,1 \mathrm{~g})$ in tekočini $(\mathrm{DPV}=1374$ $\mathrm{ml}, \mathrm{PV}=2200 \mathrm{ml}$ ). Kot je razvidno iz Tabele 1 , so se vrednosti posameznih hranil med dnevi lahko precej razlikovale. Tako je na primer petkov jedilnik vseboval $39 \mathrm{~g}$ maščob, nedeljski pa $111 \mathrm{~g}$ maščob, priporočena dnevna vrednost pa znaša 68,03 g maščob.

\section{Deleži povprečnih ostankov hranil pri starejših}

$\mathrm{Za}$ vsakega starejšega, vključenega $\mathrm{v}$ raziskavo, smo izračunali, kolikšen je bil delež ostanka pri posameznem hranilu $\mathrm{v}$ povprečju enega tedna. $\mathrm{Na}$ podlagi ugotovljene vrste in količine nezaužite hrane smo za ostanek izračunali energijsko vrednost ter vrednost makro- in mikrohranil. Tabela 3 prikazuje povprečje ostanka posameznega hranila, minimalni in maksimalni ostanek ter mediano in kvartile. S pomočjo Mann-Whitneyevega U-testa smo za vsako posamezno hranilo tudi preverili, ali se med moškimi in ženskami kažejo statistično značilne razlike.

Moški so imeli v povprečju največji ostanek pri vitaminu C (21\%) in najnižjega pri železu (14\%). Slednje pomeni, da so moški v povprečju zaužili $79 \%$ ponujenega vitamina $\mathrm{C}$ ter $86 \%$ ponujenega železa. Ženske so najvišji povprečni ostanek dosegle pri vitaminu $\mathrm{D}$, vitaminu $\mathrm{C}$ in vitaminu $\mathrm{B}_{6}$ (povsod po $27 \%$ ), najnižji ostanek pa so imele pri ogljikovih hidratih in železu (oboje po $19 \%$ ). Moški in ženske se statistično pomembno $(p<0,05)$ razlikujejo v deležu ostanka naslednjih hranil: maščobe (povprečni ostanek za moške $\left(\mathrm{PO}_{\mathrm{M}}\right)=16 \%$, povprečni ostanek za ženske $\left.\left(\mathrm{PO}_{\check{Z}}\right)=24 \%, p=0,036\right)$, holesterol $\left(\mathrm{PO}_{\mathrm{M}}=15 \%, \mathrm{PO}_{\check{Z}}\right.$ $=26 \%, p=0,035)$, vitamin $\mathrm{D}\left(\mathrm{PO}_{\mathrm{M}}=15 \%, \mathrm{PO}_{\check{Z}}=27 \%\right.$, $p=0,017)$ in vitamin $\mathrm{B}_{12}\left(\mathrm{PO}_{\mathrm{M}}=17 \%, \mathrm{PO}_{\check{Z}}=25 \%, p=\right.$ 0,016). Pri energiji, beljakovinah, ogljikovih hidratih, omega-3-maščobnih kislinah, omega-6-maščobnih kislinah, prehranskih vlakninah, vitaminu $C$, vitaminu $\mathrm{B}_{6}$, folni kislini, kalciju, magneziju, železu, cinku in pri tekočini se statistično pomembne razlike $\mathrm{v}$ vnosu hranil med moškimi in ženskami niso pokazale.

\section{Ocena prehranskega stanja starejših}

$\mathrm{Za} 40$ starejših smo ocenili prehransko stanje. Ocena prehranskega stanja je temeljila na izračunu ITM (Tabela 4) in na izvedbi presejalnega testa MPP (Tabela 5). 


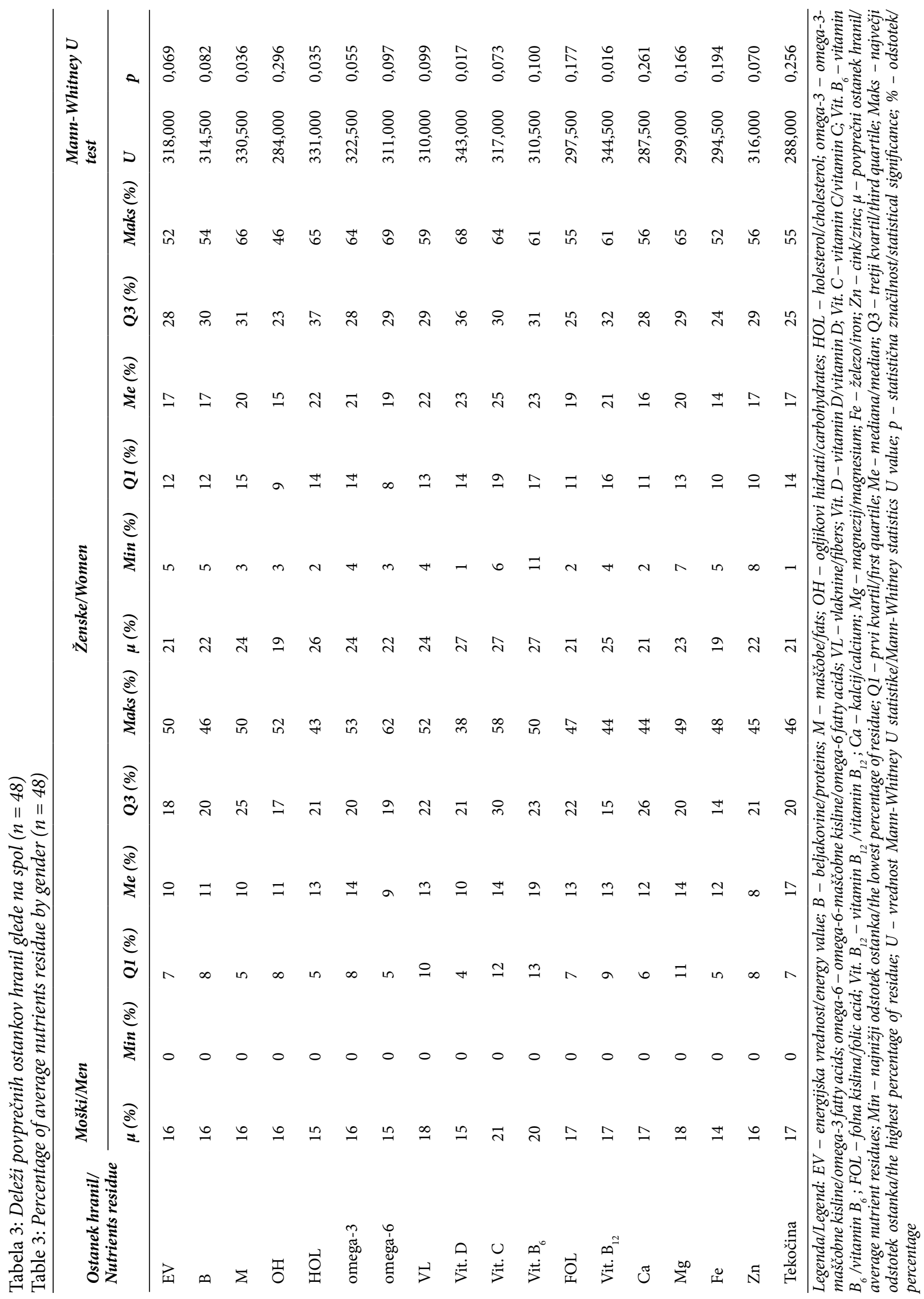


Tabela 4: Indeks telesne mase udeležencev raziskave $(n=40)$

Table 4: Body mass index of survey participants $(n=40)$

\begin{tabular}{lll}
\hline $\begin{array}{l}\text { ITM/ } \\
\boldsymbol{B M I}\end{array}$ & $\begin{array}{l}\text { ITM opisne kategorije/ } \\
\text { BMI descriptive categories }\end{array}$ & $\boldsymbol{n}(\%)$ \\
\hline$\leq 18,49$ & Podhranjenost & $/$ \\
$18,5-24,9$ & Normalna hranjenost & $2(5 \%)$ \\
$25-29,9$ & Čezmerna hranjenost & $17(42,5 \%)$ \\
$30-34,9$ & Debelost I. Stopnje & $17(42,5 \%)$ \\
$35-39,9$ & Debelost II. Stopnje & $4(10 \%)$ \\
$\geq 40$ & Debelost III. Stopnje & $/$
\end{tabular}

Legenda/Legend: ITM - indeks telesne mase/body mass index; $n$-število/number; \% - odstotek/percentage

Iz Tabele 4 je razvidno, da sta bila 2 udeleženca raziskave normalno hranjena, 17 udeležencev je bilo čezmerno hranjenih, 17 se jih je na podlagi ITM uvrstilo v kategorijo debelost I. stopnje, 4 udeleženci pa $\mathrm{v}$ kategorijo debelost II. stopnje. Za natančnejšo oceno prehranskega stanja pri starejših $(n=40)$ smo ovrednotili tudi točke, dosežene na vprašalniku MPP (Tabela 5).

Tabela 5: Mini prehranski pregled udeležencev raziskave $(n=40)$

Table 5: Results of the mini nutritional assessment $(n=40)$

\begin{tabular}{|c|c|c|}
\hline $\begin{array}{l}\text { Prvi del MPP } \\
\text { vprašalnika/ } \\
\text { First part } \\
\text { of the MNA } \\
\text { questionnaire }\end{array}$ & $\begin{array}{l}\text { Dosežene točke/ } \\
\text { Achieved points }\end{array}$ & $n(\%)$ \\
\hline \multirow{3}{*}{ MPP1 } & 12 do 14 & $38(95 \%)$ \\
\hline & 8 do 11 & $2(5 \%)$ \\
\hline & 0 do 7 & / \\
\hline Skupaj & & $40(100 \%)$ \\
\hline
\end{tabular}

Legenda/Legend: MPP/MNA - Mini prehranski pregled/Mini nutritional assessment; $n$ - število/number; \% - odstotek/percentage

Rezultati prvega dela prehranskega pregleda, tj. presejanja (MPP1), so pokazali tveganje za podhranjenost za dva udeleženca (8 do 11 točk). Izvedba poglobljene ocene prehranskega statusa (MPP2) je pokazala, da je bil en udeleženec (2,5\% udeležencev) $s$ tveganjem za podhranjenost normalno hranjen ( 24 do 30 točk), za drugega pa je pregled MPP2 potrdil tveganje za podhranjenost (17 do 23,5 točke) (2,5\% udeležencev).

\section{Diskusija}

$\mathrm{V}$ raziskavi so nas vodila raziskovalna vprašanja, usmerjena $\mathrm{v}$ analizo: (1) skladnosti jedilnikov $\mathrm{v}$ socialnovarstvenem zavodu s priporočili; (2) ostanka posameznih hranil pri starejših; (3) razlik med moškimi in ženskami v ostanku posameznih hranil ter (4) prehranskega stanja starejših. Z analizo jedilnikov za starejše smo ugotovili, da nekatera hranila s svojimi vrednostmi od priporočil (Nacionalni inštitut za javno zdravje, 2016) odstopajo. $Z$ vidika makrohranil so to predvsem maščobe, ki s povprečnim tedenskim deležem 32,9 \% celotne količine energije presegajo priporočila (Gabrijelčič Blenkuš, et al., 2010; Nacionalni inštitut za javno zdravje, 2016). Delež prispevka makrohranil k skupnemu energijskemu vnosu se med dnevi v tednu tudi zelo razlikuje. Tako npr. delež maščob niha med $20 \%$ v petek in $45 \%$ (tj. precej nad priporočili) v nedeljo. Previsok vnos maščob je povezan s pojavom čezmerne telesne mase in debelostjo ter boleznimi srca in ožilja (Gabrijelčič Blenkuš, et al., 2010). V jedilnikih bi lahko zmanjšali delež maščob na račun povečanja deleža sestavljenih ogljikovih hidratov. Starostnikom bi lahko pri obrokih ponudili manj mastne izdelke (npr. posneto mleko, pusto meso), ribe, oreščke in več polnozrnatih izdelkov, sadja ter zelenjave, tako bi jedilniki vsebovali tudi več prehranskih vlaknin, omega-3-maščobnih kislin, vitamina $\mathrm{D}$ ter manj holesterola.

Skoraj vsi vitamini in minerali, vključeni v analizo, so $\mathrm{s}$ svojimi vrednostmi presegli priporočilo, vendar so $\mathrm{v}$ skladu s priporočili še $\mathrm{v}$ dopustnih mejah. Izjemi sta bili vitamin $\mathrm{D}$, katerega vrednosti so se gibale krepko pod priporočilom, in železo, ki je bilo s svojo vrednostjo vsak dan nad priporočilom. Tudi iz raziskav drugih (Elmadfa \& Meyer, 2008) je razvidno pomanjkanje vitamina D v prehrani med starejšimi, le-to pa ima lahko pomemben vpliv na zdravje starejših. Sawka in sodelavci (2010) potrjujejo, da vitamin $D$, predvsem vnos vitamina $D_{3} v$ vrednosti $\geq 800$ IE peroralno dnevno, zmanjša tveganje za zlom kolka, saj pripomore $\mathrm{k}$ boljši absorpciji kalcija. Pomen zagotavljanja vnosa vitamina $\mathrm{D}$ v vrednosti 7000-1000 IE (17,5-25 $\mu \mathrm{g})$ priporočajo tudi do sedaj opravljeni sistematični pregledi in metaanalize literature (Leslie \& Hankey, 2015). V človeški koži, če je le-ta izpostavljena sončni svetlobi, se le-ta $\mathrm{v}$ zadostni meri biosintetizira, tako da med pomladjo in jesenjo dnevne potrebe lahko pokrijemo že s 15-minutno zmerno izpostavljenostjo soncu, npr. s sprehodom, če so soncu izpostavljene roke in obraz (Nacionalni portal o hrani in prehrani, n. d.).

V literaturi smo zasledili zgornjo še dovoljeno mejo za dnevni vnos železa za starejše, in sicer je zgornja dovoljena dnevna količina železa, ki znaša za odrasle, 
stare med 51 in 70 let, ter za starejše od 70 let $45 \mathrm{mg}$ (Escott-Stump, 2015). Prekomeren vnos železa povzroča obstipacijo, slabost, bruhanje in drisko (Rolfes, et al., 2009), železo namreč lahko hitro spremeni svoje oksidacijsko stanje in ustvari kisikove proste radikale, ki so za celice izjemno strupeni in jih poškodujejo. Vnos železa mora biti zato v ravno pravih mejah, saj previsoki odmerki lahko poškodujejo jetra, trebušno slinavko in srce (Nacionalni portal o hrani in prehrani, n. d.). V skladu s tem menimo, da bi vrednosti železa v jedilnikih za starejše lahko dosegale nižje vrednosti, saj le-to lahko deluje prooksidativno (Fraga, 2005; Nacionalni portal o hrani in prehrani, n. d.).

Drugo in tretje zastavljeno raziskovalno vprašanje se nanašata na analizo ostankov hrane in razlik med moškimi in ženskami $\mathrm{v}$ ostanku hranil. Na podlagi raziskave ugotavljamo, da se ostanki $\mathrm{v}$ povprečju pojavljajo pri vseh hranilih. Razpon minimalnega in maksimalnega deleža ostankov hranil $\mathrm{v}$ skupini udeležencevnakazujenavelikerazlikemed posamezniki. Tako npr. ostanek omega-6-maščobnih kislin pri moških niha od 0 do $62 \%$, kar kaže na posameznike, pri katerih ni bilo ostankov tega hranila, in posameznike, pri katerih je bil ostanek več kot $60 \%$. V primerjavi $z$ moškimi so ženske v povprečju imele večje ostanke pri vseh hranilih. Statistično značilne razlike v ostankih hranil med moškimi in ženskami so se pokazale pri maščobah, holesterolu, vitaminu $\mathrm{D}$ in vitaminu $\mathrm{B}_{12}$.

Ob zaključkih glede ostankov hranil je treba opozoriti, da kuhinjsko osebje pri vsakdanjem razdeljevanju hrane upošteva tudi želje stanovalcev glede velikosti porcij in zamenjave določenih živil, zato rezultati ocenjevanja ostankov hrane in hranil niso posplošljivi, saj se v praksi ostanki spreminjajo od obroka do obroka. V raziskavi smo ocenjevali izključno hrano, ki jo pripravlja kuhinja socialnovarstvenega zavoda, upoštevati pa je treba, da nekateri starejši določene obroke izpuščajo ali odhajajo na obisk in obroke domov. Slednjega v raziskavi nismo upoštevali, saj namen raziskave ni bil ugotavljati povezanosti med ponujeno hrano in prehranskim stanjem posameznega starejšega.

Zadnje zastavljeno raziskovalno vprašanje se nanaša na oceno prehranskega stanja med udeleženci. Številni viri (van Nie-Visser, et al., 2011; Donini, et al., 2013; Riches \& Jeanes, 2014; Amorim Sena Pereira, et al., 2015) poročajo o pojavu podhranjenosti starejših $\mathrm{v}$ socialnovarstvenih zavodih, česar pa naša raziskava ne potrjuje. Podatki o vrednostih ITM za udeležence raziskave kažejo, da sta bila 2 udeleženca normalno hranjena, ostalih 38 (95\% vseh udeležencev) pa je imelo vrednost ITM, ki kaže prekomerno hranjenost ali debelost. Rezultati MPP pa so pokazali tveganje za podhranjenost pri enem udeležencu. Tudi predhodne raziskave (de Souto Barreto, et al., 2012; Lopez-Contreras, et al., 2014) ugotavljajo prisotnost prekomerne telesne mase in debelosti med starejšimi v socialnovarstvenih zavodih ter razložijo, da je debelost pri starejšimi pogosteje prisotna med mlajšimi starejšimi in med starejšimi, ki so bolj samostojni (de Souto Barreto, et al., 2012). V naši raziskavi so sodelovali le starejši stanovalci, ki so bili samostojni, vendar pa velikost vzorca ne dopušča sklepanja o morebitni povezanosti samostojnosti starejših in prekomernosti telesne mase.

Zaradi majhnega vzorca se $\mathrm{v}$ raziskavi tudi nismo odločili za ugotavljanje razlik $\mathrm{v}$ prehranjenosti med moškimi in ženskami. Dosedanje raziskave namreč nakazujejo večjo verjetnost podhranjenosti med moškimi, in sicer tako v domačem (Kvamme, et al., 2011) kot tudi $\mathrm{v}$ institucionalnem okolju (Amorim Sena Pereira, et al., 2015). Toda dokazi o tem niso povsem zanesljivi (Torres, et al., 2014) saj kažejo tudi na druge možne razloge za razlike med spoloma $\mathrm{v}$ podhranjenosti in na vpliv samega uporabljenega diagnostičnega kriterija za merjenje podhranjenosti (López-Contreras, et al., 2014). Poleg majhne velikosti vzorca večje posploševanje ni mogoče tudi zaradi omejitve strukture vzorca na samostojne in pomične stanovalce socialnovarstvenih zavodov brez večjih zdravstvenih težav. Ugotovitev torej ne moremo posploševati na celotno populacijo starejših, pa tudi ne na vse stanovalce socialnovarstvenih zavodov $\mathrm{v}$ Sloveniji. Zaradi navedenih razlogov bi bile za ustrezno oceno stanja v Sloveniji potrebne nadaljnje raziskave.

Pomembno je, da zaposleni $\mathrm{v}$ zdravstveni negi dobro poznajo individualne potrebe, želje, zmožnosti in navade starejših v socialnovarstvenih zavodih, da lahko temu prilagodijo izvajanje aktivnosti, povezanih $\mathrm{z}$ uživanjem hrane in pijače. Po mnenju Kobentar in Marinič (2000) je namreč treba upoštevati številne organskein druge motnje, kilahko vplivajonazmožnost prehranjevanja v starosti. Poleg tega imajo zaposleni v zdravstveni negi tudi možnost zdravstvenovzgojnega delovanja $\mathrm{v}$ primeru, ko ugotovijo pomanjkanje znanja ali potrebo po spreminjanju prehranjevalnih navad pri starejšemu, oz. mu pomagajo pri ohranjanju zdravih vedenjskih vzorcev, povezanih $\mathrm{z}$ uživanjem hrane in pijače. Če želimo individualne potrebe posameznika uskladiti s prehranskimi priporočili in smernicami za starejše, je nenazadnje nujno potrebno tudi medpoklicno sodelovanje.

\section{Zaključek}

Kljub omejitvam raziskave pridobljeni rezultati opozarjajo na potrebo po nadzoru kakovosti prehrane starejših v socialnovarstvenem zavodu, saj je analiza pokazala odstopanja od priporočenih vrednosti makrohranil (maščobe, tekočina) in mikrohranil (predvsem vitamin $\mathrm{D}$ in železa) ter nakazala možno prisotnost prekomerne telesne mase in debelosti pri starejših. Ustrezen vnos hranil pri starejših, vključenih $\mathrm{v}$ socialnovarstvene zavode, lahko zagotovimo $\mathrm{z}$ rednim spremljanjem ponujene in zaužite hrane ter $\mathrm{z}$ rednim tedenskim izvajanjem prehranskega presejanja. Individualni prehranski načrt predstavlja možnost in priložnost, s katero bi se na področju zagotavljanja 
kakovostne prehranske obravnave bolj približali značilnostim starejšega kot posameznika. $\mathrm{V}$ tem delu se vlogi zdravstvene nege in dietetike nepogrešljivo in nujno prepletata.

\section{Nasprotje interesov/Conflict of interest}

Avtorice izjavljajo, da ni nasprotja interesov./The authors declare that no conflicts of interest exist.

\section{Financiranje/Funding}

Raziskava ni bila finančno podprta./The study received no funding.

\section{Etika raziskovanja/Ethical approval}

Raziskava je pripravljena v skladu z načeli HelsinškoTokijske deklaracije (World Medical Association, 2013)./The study was conducted in accordance with the Helsinki-Tokyo Declaration (World Medical Association, 2013).

\section{Prispevek avtorjev/Author contributions}

Prva in vodilna avtorica sta načrtovali raziskavo in sodelovali v pripravi vseh delov članka (Uvod, Metode, Rezultati (analiza in opis rezultatov), Diskusija in Zaključek). Druga in tretja avtorica sta sodelovali pri pripravi Uvoda, Metod, Rezultatov (opis rezultatov), Diskusije in Zaključka./The first author and the leading author designed the study and participated in the writing of the following sections: Introduction, Methods, Results (analysis and description of results), Discussion and Conclusion. The second author and the third author participated in the writing of the following sections: Introduction, Methods, Results (description of results), Discussion and Conclusion.

\section{Literatura}

Amorim Sena Pereira, M.L., de Almeida Moreira, P., Cunha de Oliveira, C., Carneiro Roriz, A.K., Reis Amaral, M.T., Lima Mello, A., et al., 2015. Nutritional status of institutionalized elderly Brazilians: a study with the Mini Nutritional Assessment. Nutricion Hospitalaria, 31(3), pp. 1198-1204.

http://dx.doi.org/10.3305/nh.2015.31.3.8070

Bjornsdottir, R. Oskarsdottir, E.S., Thordardottir, F.R., Ramel, A., Thorsdottir, I. \& Gunnarsdottir, I., 2013. Validation of a plate diagram sheet for estimation of energy and protein intake in hospitalized patients. Clinical Nutrition, 32(5), pp. 746-751. http://dx.doi.org/10.1016/j.clnu.2012.12.007

van Bokhorst-de van der Schueren, M.A.E., Soeters, P.B., Reijven, P.L.M., Allison, S.P. \& Kondrup J., 2011. Diagnosis of malnutrition - screening and assessment. In: L. Sobotka, ed. Basics in Clinical Nutrition. 4th ed. Prague: Galen, pp. 21-32.
Cederholm, T., 2015. Epidemiology, aetiology and consequences of malnutrition in older adults. ESPEN LLL Programme. Available at:

http://llnutrition.com/mod lll/TOPIC36/m361.pdf [10. 5. 2017].

Cederholm, T., Barazzoni, R., Austin, P., Ballmer, P., Biolo, G., Bischoff, S. C., et al., 2017. ESPEN guidelines on definitions and terminology of clinical nutrition. Clinical Nutrition, 36(1), pp. 49-64.

https://doi.org/10.1016/j.clnu.2016.09.004

Deutz, N.E., Bauer, J.M., Barazzoni, R., Biolo, G., Boirie, Y., BosyWestphal, A., et al., 2014. Protein intake and exercise for optimal muscle function with aging: recommendations from the ESPEN Expert Group. Clinical Nutrition, 33(6), pp. 929-936.

https://doi.org/10.1016/j.clnu.2014.04.007.

Donini, L.M., Neri, B., De Chiara, S., Poggiogalle, E., \& Muscaritoli, M., 2013. Nutritional care in a nursing home in Italy. Plos ONE, 8(2), art. ID e55804, pp. 1-10.

https://doi.org/10.1371/journal.pone.0055804

Drewnowski, A., Monsen, E., Birkett, D., Gunther, S., Vendeland, S., Su, J., et al., 2003. Health screening and health promotion programs for the elderly. Disease Management \& Health Outcomes, 11(5), pp. 299-309.

https://doi.org/10.2165/00115677-200311050-00003

Eide, H.D., Halvorsen, K. \& Almendingen, K., 2015. Barriers to nutritional care for the undernourished hospitalised elderly: perspectives of nurses. Journal Of Clinical Nursing, 24(5/6), pp. 696-706.

https://doi.org/10.1111/jocn.12562

PMid:24646060; PMCid:PMC4359674

Elmadfa, I., \& Meyer, A.L., 2008. Body composition, changing physiological functions and nutrient requirements of the elderly. Annals Of Nutrition \& Metabolism, 52(Suppl 1), pp. 2-5. https://doi.org/10.1159/000115339

Escott-Stump, S., 2015. Nutrition and diagnosis-related care. 8th ed. Philadelphia: Wolters Kluwer, p. 64.

ESPEN, n. d. Unit resident list and outcomes. Available at: https://www.nutritionday.org/cms/front content.php?idart=531 [10.5.2017].

Fakhouri, T.H., Ogden, C.L., Carroll, M.D., Kit, B.K., \& Flegal, K.M., 2012. Prevalence of obesity among older adults in the United States, 2007-2010. National Center for Health Statistics data brief, 106, pp. 1-8. Available at:

https://www.cdc.gov/nchs/data/databriefs/db106.pdf [10. 5. 2017].

Fraga, C.G., 2005. Relevance, essentiality and toxicity of trace elements in human health. Molecular aspects of medicine, 26(4/5), pp. 235-244.

https://doi.org/10.1016/j.mam.2005.07.013 
Gabrijelčič Blenkuš, M., Stanojević Jerković, O., Đukič, B., Prezelj, M., Ješe, M., Škornik Tovornik, T., et al., 2010. Prehrana in telesna dejavnost za zdravje pri starejših - pregled stanja. Ljubljana: Inštitut za varovanje zdravja Republike Slovenije. Available at: http://www.nijz.si/sites/www.nijz.si/files/uploaded/ prehranaintelesnadejavnostsarejsh 4940.pdf [29. 1. 2016].

Gorjup Poženel, D. \& Skela Savič, B., 2013. Vloga zdravstvene nege pri prehranski ogroženosti starostnikov. Kakovostna starost, 16(2), pp. 13-21.

Guigoz, Y. 2006. The Mini-Nutritional Assessment (MNA $\left.{ }^{\star}\right)$ Review of the literature - What does it tell us? The Journal of nutrition, health \& aging, 10, pp. 466-487.

https://doi.org/10.1038/oby.2004.83

Gutiérrez-Fisac, J.L., Lopez E., Banegas J.R., Graciani A. \& Rodriguez-Artalejo, F., 2004. Prevalence of overweight and obesity in elderly people in Spain. Obesity research, 12(4), pp. 710-715.

https://doi.org/10.1038/oby.2004.83

Hlastan Ribič, C., Šerona, A., Maučec Zakotnik, J. \& Borovničar, A., 2012. Čezmerna hranjenost in debelost. In: J. Maučec Zakotnik, S. Tomšič, T. Kofol Bric, A. Korošec \& L. Zaletel Kragelj, eds. Zdravje in vedenjski slog prebivalcev Slovenije: trendi v raziskavah CINDI 2001-2004-2008. Ljubljana: Inštitut za varovanje zdravja Republike Slovenije, p. 151.

Hlebec, V., Kavčič, M. \& Ogulin Počrvina, G., 2013. Staranje, izziv za izobraževanje in medgeneracijsko sodelovanje. Ljubljana: Zveza ljudskih univerz Slovenije, 2013.

Inštitut Jožef Stefan, n. d. OPKP - Odprta platforma za klinično prehrano. Available at:

http://www.opkp.si/sl SI/cms/vstopna stran [30. 3. 2016].

Kobentar, R. \& Marinčič, M., 2000. Organske spremembe in motnje prehranjevanja v starosti. Obzornik zdravstvene nege, 34(5/6), pp. 209-214. Available at:

http://www.obzornikzdravstvenenege.si/2000.34.3.209 [30.3.2016].

Kvamme, J., Olsen, J., Florholmen, J. \& Jacobsen, B., 2011. Risk of malnutrition and health-related quality of life in communityliving elderly men and women: the Troms $ø$ study. Quality Of Life Research, 20(4), pp. 575-582.

https://doi.org/10.1007/s11136-010-9788-0

PMid:21076942; PMCid:PMC3075394

Leslie, W. \& Hankey, C., 2015. Aging, nutritional status and health. Healthcare, 3(3), pp. 648-658.

https://doi.org/10.3390/healthcare3030648

López-Contreras, M. J., López, M. Á., Canteras, M., Candela, M. E., Zamora, S., \& Pérez-Llamas, F., 2014. Identification of different nutritional status groups in institutionalized elderly people by cluster analysis. Nutricion Hospitalaria, 29(3), pp. 602-610.

https://doi.org/10.3305/nh.2014.29.3.7194
Ministrstvo za zdravje RS, 2008. Priporočila za prehransko obravnavo bolnikov $v$ bolnišnicah in starostnikov $v$ domovih $z a$ starejše občane. Available at:

http://www.mz.gov.si/fileadmin/mz.gov.si/pageuploads/javno zdravje 09/Priporocila za prehransko obravnavo bolnikov. pdf [16. 12. 2016].

Nacionalni inštitut za javno zdravje, 2016. Referenčne vrednost $i$ za energijski vnos ter vnos hranil: tabelarična priporočila za otroke (od 1. leta starosti naprej), mladostnike, odrasle, starejše, nosečnice ter doječe matere. Available at:

http://www.mz.gov.si/07007943.php/delovna podrocja in prioritete/javno zdravje/varovanje in krepitev zdravja/ prehrana/strateske usmeritve smernice in publikacije/[17.4. 2016].

Nacionalni portal o hrani in prehrani, n. d. Vitamin D. Inštitut za nutricionistiko. Available at:

http://prehrana.si/sestavine-zivil/vitamini/vitamin-d [19. 5. 2017].

van Nie-Visser, N.C., Meijers, J.M., Schols, J.M., Lohrmann, C., Bartholomeyczik, S., \& Halfens, R.J., 2011. Comparing quality of nutritional care in Dutch and German nursing homes. Journal Of Clinical Nursing, 20(17/18), pp. 2501-2508.

https://doi.org/10.1111/j.1365-2702.2011.03761.x

Poklar Vatovec, T. 2013. Prehransko presejanje v domu za starejše občane. In: G. Valenčič, ed. Prehrana starostnika: zbornik predavanj. Ljubljana: Strokovna sekcija medicinskih sester in zdravstvenih tehnikov v socialnih zavodih, pp. 47-57.

Poklar Vatovec, T., Bizjak, M. \& Jakus, T., 2013. Praktično usposabljanje III: praktikum: podiplomski študij Dietetika. Koper: Založba Univerze na Primorskem. Available at: http://www.fvz.upr.si/sites/default/files/f 1046.pdf [6. 2. 2016].

Power, S.E., Jeffery, I.B., Ross, R.P., Stanton, C., O’Toole, P.W., O'Connor, E.M., et al., 2014. Food and nutrient intake of Irish community-dwelling elderly subjects: who is at nutritional risk? Journal of nutrition, health, and aging, 18(6), pp. 561-572. https://doi.org/10.1007/s12603-014-0449-9

Razpotnik, B., 2017. Projekcije 2015: v 2080 naj bi bilo prebivalcev Slovenije manj kot danes, delež starejših višji. In: Projekcije prebivalstva za Slovenijo. Statistični urad Republike Slovenije. Available at: http://www.stat.si/StatWeb/prikazi-novico?id=6584 [3. 7. 2017].

Resolucija o nacionalnem programu o prehrani in telesni dejavnosti za zdravje 2015-2025, 2015. Uradni list Republike Slovenije št. 58.

Riches, K., \& Jeanes, Y., 2014. The prevalence of malnutrition in elderly residents in a warden-assisted setting compared with a home-living environment. British Journal of Community Nursing, 19(7), pp. 324-327.

https://doi.org/10.12968/bjcn.2014.19.7.324

PMid:25039339 
Rolfes, S.R., Pinna, K., \& Whittney, E., 2009. Understanding normal and clinical nutrition. 8th ed. Belmont: Wadsworth Cengage Learning, pp. 447-449. Available at:

http://www.uphsl.edu.ph/library/ebooks/Medical/Understanding\% 20Normal\%20\&\%20Clinical\%20Nutrition\%202.pdf [19.5.2017].

Sawka, A. M., Ismaila, N., Cranney, A., Thabane, L., Kastner, M., Gafni, A., et al., 2010. A scoping review of strategies for the prevention of hip fracture in elderly nursing home residents. Plos ONE, 5(3), art. ID e9515, pp. 1-10.

https://doi.org/10.1371/journal.pone.0009515

de van der Schueren, M.A.E., 2015. Nutritional screening, assessment and diagnosis dietary advice and oral nutritional supplements in older adults. ESPEN LLL Programme. Available at: http://lllnutrition.com/mod 1ll/TOPIC36/m362.pdf [10. 5. 2017].

Skela Savič, B., Hvalič T.S. \& Zurc, J., 2010. Staranje populacije, potrebe starostnikov in nekateri izzivi za zdravstveno nego. Obzornik zdravstvene nege, 44(2), pp. 89-100. Available at: http://www.obzornikzdravstvenenege.si/Celoten clanek. aspx? $\mathrm{ID}=582 \mathrm{e} 6 \mathrm{ede}-9 \mathrm{bf2}-4 \mathrm{e} 25-842 \mathrm{c}-8675 \mathrm{aa} 56283 \mathrm{c}$ [10. 5. 2017].

de Souto Barreto, P., Zanandrea, V., Lapeyre-Mestre M., Cesari, M., Vellas, B. \& Rolland, Y., 2015. Obesity in nursing home residents: a cross-sectional study. Journal of Nursing Home Research, 1, pp. 6-10. Available at:

http://www.jnursinghomeresearch.com/all-issues.html? $\mathrm{a}=2015 \& \mathrm{n}=01$ [12.5.2017].
World Medical Association, 2013. World Medical Association Declaration of Helsinki: ethical principles for medical research involving human subjects. Journal of the American Medical Association, 310(20), pp. 2191-2194. Available at: http://www.wma.net/en/20activities/10ethics/10helsinki/ DoH-Oct2013-JAMA.pdf [30. 6. 2017].

Thomas, J.M., Cooney, L.M., \& Fried, T.R., 2013. Systematic review: health-related characteristics of elderly hospitalized adults and nursing home residents associated with short-term mortality. Journal Of The American Geriatrics Society, 61(6), pp. 902-911.

https://doi.org/10.1111/jgs.12273

Torres, M. J., Dorigny, B., Kuhn, M., Berr, C., Barberger-Gateau, P., \& Letenneur, L. 2014. Nutritional status in communitydwelling elderly in France in urban and rural areas. Plos ONE, 9(8), art. ID e105137, pp. 1-8.

https://doi.org/10.1371/journal.pone.0105137

Zakon o socialnem varstvu, 2007. Uradni list Republike Slovenije, št. 3.

Citirajte kot/Cite as:

Urh, N., Babnik, K., Rebec, D. \& Poklar Vatovec, T., 2017. Ocena prehranskega stanja starejših v socialnovarstvenem zavodu. Obzornik zdravstvene nege, 51(3), pp. 207-218. https://doi.org/10.14528/snr.2017.51.3.167 